Удк 340.155.2(343.8)

\author{
Сокальська О. В., \\ кандидат юридичних наук, доцент, \\ старший науковий співробітник \\ науково-дослідного центру з питань \\ діяльності органів та установ Державної \\ кримінально-виконавчої служби України \\ і пробації Інституту \\ кримінально-виконавчої служби \\ Ісевич O. I., \\ здобувач вищої освіти ступеня «магістр» \\ Інституту кримінально-виконавчої служби
}

\title{
В'ЯЗНИЧНА СИСТЕМА КОРОЛІВСТВА ШВЕЦІЯ: ЕТАПИ СТАНОВЛЕННЯ ТА СУЧАСНИЙ СТАН
}

У статті розглянуто етапи становлення в'язничної системи Королівства Швеція від XIX ст. і до сьогодення, особливу увагу звернуто на реформи 3040 років XX ст. як такі, що стали основою для формування сучасної в'язничної системи Швеції, визначено правові та організаційні засади функціонування установ виконання покарань, особливості режиму та умов утримання в карних закладах різних типів.

Ключові слова: Королівство Швеція, в'язнична система, Карл Шлітер, пенітенціарна реформа, Кримінальний кодекс Швеції, праця засуджених, умови тримання засуджених.

В статье рассмотрены этапы становлення тюремной системы Королевства Швеция от XIX в. и до современности, особое внимание уделено реформам 30-40 годов XX века, которые стали основой формирования современной тюремной системы Швеции, определены правовые и организационные принципы функционирования учреждений исполнения наказаний, особенности режима и условий содержания в тюрьмах разных классов.

Ключевые слова: Королевство Швеция, тюремная система, Карл Шлитер, пенитенциарная реформа, Уголовный кодекс Швеции, труд осужденных, условия содержания осужденных.

Постановка проблеми. Актуальність дослідження питань функціонування в'язничних систем провідних країн світу зумовлена потребою у використанні позитивного зарубіжного досвіду в процесі перебудови та реформування вітчизняної кримінально-виконавчої системи, а також браком спеціальних досліджень із цієї проблематики.

Аналіз останніх досліджень і публікацій. У зарубіжній історіографії компаративістські, у тому числі й історичні, дослідження правових систем загалом та окремих їх елементів уже давно посідають почесне місце. 
Вітчизняні науковці, зокрема М. Пузирьов, теж неодноразово зверталися до порівняльно-правових досліджень, зокрема і в питаннях кримінально-виконавчого права. Так, у навчальному посібнику «Порівняльне кримінально-виконавче право» розглянуто окремі види покарань та окреслено особливості їх виконання, зокрема і за шведським кримінальним законодавством. У підручниках 3 кримінально-виконавчого права кримінально-виконавчі системи та організація виконання покарань у виді позбавлення волі в зарубіжних країнах згадуються лише побічно. Окремі аспекти відбування покарання в тюрмах Швеції висвітлено в спеціальних розвідках знаних вітчизняних учених О.Лисодєда та А. Степанюка [1; 2]. Однак в історичній ретроспективі в'язнична система Швеції вітчизняними дослідниками не розглядалася. Етапи становлення та сучасний стан пенітенціарних систем скандинавських країн, зокрема й Швеції, розглянуто відомою польською дослідницею М. Платек (M. Płatek) [3]. Особливий інтерес 3 огляду на визначену тематику становлять праці сучасних шведських, норвезьких та данських дослідників: Р. Нілссон (R. Nilsson), П.С. Сміта (P.S. Smith), Т. Угельвіка (T. Ugelvik) i В. Шаммаса (V. L. Shammas) $[4 ; 5 ; 6 ; 7]$.

Постановка завдання. Метою цієї статті є характеристика й аналіз основних етапів становлення в'язничної системи Швеції, правових та організаційних засад діяльності установ виконання покарань у виді позбавлення волі, умов і режиму виконання даного виду покарання у в'язницях різного рівня безпеки.

Виклад основного матеріалу. Початковий етап формування в'язничної системи Швеції припадає на середину XIX ст. До цього часу будівництво нових тюрем переважно було пов'язано з військовими потребами (Швеція вела активну боротьбу з Данією за сфери впливу в регіоні Aвm.). Отже, особи, засуджені до каторжних робіт, повинні були зводити оборонні споруди, які одночасно виконували й функції в'язниць.

Нові для Європи пенітенціарні ідеї щодо виправлення злочинців не оминули й Швецію. В'язнична реформа в країні розпочалася 1840 р. і тривала до 1894 р. У результаті відкрито три пенітенціарії для чоловіків і один - для жінок; 46 одиночних тюрем, три центральні тюрми 3 примусовими роботами для чоловіків, одна - для жінок, одна - для молодих волоцюг та неповнолітніх злочинців, яким призначено виправне покарання. Більшість засуджених до позбавлення волі відбували покарання в одиночних камерах. А ті, хто відбував тривале покарання - лише перші 3 роки перебували в суворому одиночному ув'язненні [8].

У Швеції переважно впроваджувалася філадельфійська система одиночного утримання, що дозволяло підтримувати високий рівень тюремної дисципліни. Особливого значення за такого режиму набула діяльність місцевих протестантських капеланів, які виконували роль і психологів, і педагогів, і душпастирів. Показово, що навіть після визнання того, що реабілітаційний ефект одиночного утримання незначний або ж воно навіть шкідливе, застосування у Швеції цієї моделі продовжувалося $[4 ; 5]$.

Новий Кримінальний кодекс Швеції, який суттєво гуманізував покарання, ухвалено 1864 р. На поча- 
тку ХХ ст. до нього внесено зміни: 1906 р. упроваджено умовнодострокове звільнення, 1918 р. відстрочка тюремного ув'язнення 3 випробувальним строком [3, s. 245248].

Прихід до влади 1932 р. уряду соціал-демократів став переломним моментом у новітній історії Швеції. Власне, ним закладено основи держави загального добробуту. Соціальні реформи, започатковані урядом, не оминули і кримінальної політики, зокрема сфери виконання покарань. Міністром юстиції було призначено знаного юриста, члена парламенту, суддю апеляційного суду одного 3 регіонів Швеції Карла Шлітера (Karl Schlyter), який невдовзі презентував пропозиції до плану реформ системи покарань та тюремних перетворень [9, p. 507].

Новий міністр не був прихильником широкого застосування тюремного ув'язнення. У своїй доповіді «Депопуляція тюрем» 1934 р. К. Шлітер зазначав, що основне завдання адміністрації тюрем - привчити засудженого до праці й порядку. Моральний та виховний вплив мають спонукати злочинця до суспільно-корисної праці, що дозволить йому повернутися до правослухняного життя й забезпечити себе після звільнення. Захист суспільства - основна мета кримінального закону, найбільш ефективно досягається за допомогою індивідуальних превентивних заходів і соціальної профілактики, а не суворого покарання. [6, p. 40-41].

На переконання К. Шлітера, слід дивитися не в минуле (що вчинив злочинець), а вперед - що можна зробити з ним чи для нього в майбутньому, щоб він став законослухня- ним громадянином. Міністр наполягав на застосуванні не санкцій, а «захисних засобів», які мають на меті реінтеграцію правопорушника в суспільство, а також створенні окремих спеціалізованих закладів для молодих правопорушників та жінок [9, p. 511]. Проявом соціальної несправедливості називав К. Шлітер тюремне ув'язнення для тих, хто не в змозі сплатити штраф. Унаслідок реформи кількість таких засуджених скоротилася з 11000 у 1930 р. до 650 1940 p. [9, p. 507].

1935 року міністерством юстиції представлено проект «молодіжної» тюрми нового типу. За зразок узято данський карний заклад для неповнолітніх у Сьобисьогард, започаткований 1933 р., у якому особливу увагу звертали на освітні заходи.

Після відставки К. Шлітера 1936 р. розпочата робота не припинилася, він очолив урядову Комісію 3 реформування кримінального законодавства (Комісію), що займалася i питаннями в'язничної системи. Саме погляди К. Шлітера як голови Комісії стали визначальними при окресленні вектора кримінальної політики Швеції наприкінці 30-40 років ХХ ст. Членами Комісії активно вивчався прогресивний зарубіжний досвід, було налагоджено співробітництво між юристами та представниками тюремних адміністрацій країн Північної Європи.

Новаторські погляди реформаторів були нормативно закріплені 1938 р. у Тюремній інструкції. У ній визначалося, що засуджені повинні утримуватися в місцях позбавлення волі в таких умовах, які сприяли б перетворенню їх у законослухняних громадян і пристосовували до життя в суспільстві. Особливе місце серед 
засобів виправлення відводилося праці засуджених. Також під час виконання покарання слід було звертати увагу на вік, розумовий і фізичний розвиток, характер, здібності й освіту засуджених [6, p. 41-42].

Наступний етап реформування системи виконання покарань Швеції розпочато у повоєнний період. 1945 року ухвалено Закон про виконання покарань, розроблений 1944 р. Комісією. Він, з поміж іншого, скасовував суворе одиночне утримання за філадельфійською системою та визначав принципи виконання покарань, зокрема: ставитися до засуджених строго, але 3 повагою до людської гідності; задля виправлення засуджений має бути постійно зайнятий роботою; умови утримання мали сприяти реінтеграції в суспільство; негативний вплив позбавлення волі на особистість злочинця має бути мінімізований, наскільки це можливо; тюремне ув'язнення не повинно бути стражданням заради страждання. Ідея цінності людського життя, що набула особливої актуальності після жахіть Другої світової війни, у шведському Законі про виконання покарань 1945 р. була поширена і на злочинців [9, p. 512].

У повоєнний період відбулося стрімке зростання економіки Швеції через підвищений попит на промислові товари з-за кордону. Відчутним був брак робочої сили. Державна політика передбачала повну трудову зайнятість усього населення. Праця стала символом добробуту країни. На відміну від Тюремної інструкції 1938 р., у Законі про виконання покарань 1945 р. праця визначалася ключовим обов'язковим елементом тюремного ув'язнення. Тюремній адміністрації рекомендувалося фор- мувати позитивне ставлення до праці, облаштовувати просторі виробничі цехи з гідними умовами й сучасним обладнанням, щоб стимулювати засуджених. Вони отримали право працювати за межами установ виконання покарань. До кінця 60-х років за належної організації праці у в'язницях її ефективність зросла майже вдвічі [6, p. 43, 48].

1962 року ухвалено новий Кримінальний кодекс Швеції (набрав чинності 1965 р.), який передбачав гуманне, але ефективне поводження 3 правопорушниками [10]. Відтоді розпочалося формування основних принципів сучасної пенітенціарної системи: прозорість, відсутність цензури, гідні умови утримання, велика кількість карних установ «відкритого» типу, можливість короткочасних відпусток для засуджених, підтримка соціальних зв'язків з родичами. Але особливу увагу було звернуто на «трудову програму», що стала, так би мовити, візитівкою кримінальновиконавчої системи Швеції. Її мета максимально наблизити умови праці в місцях несвободи до тих, що існують на звичайних підприємствах. Також вона передбачала широке залучення інвесторів для створення нових робочих місць у в'язницях [6, p. 43,48$]$.

Система покарань та установ відбування покарань, установлена Кримінальним кодексом 1962 р., діє і дотепер. Відповідно до Кримінального кодексу Швеції тюремне ув'язнення може бути довічним або призначатися на строк від 14 діб до 10 років. Як виняток, за вчинення тяжких злочинів може бути призначено тюремне ув'язнення строком до 16 років. За загальним правилом, особа повинна бути умовно звільне- 
на від відбування цього покарання після відбуття 2/3 строку, але не менше ніж через один місяць [11, с. 71]. У Швеції тюремне ув'язнення вважається крайнім каральним заходом, якого, за можливості, слід уникати при призначенні покарання. 2011 року набрав чинності Закон «Про позбавлення волі», що регламентує усі аспекти реалізації даного виду покарання.

Виконання покарань та альтернативних їм заходів у Швеції покладено на Службу тюрем і пробації у складі міністерства юстиції, що формує державну політику в сфері виконання покарань, але безпосередньо не впливає на роботу Служби. 1974 року реформовано організаційно-управлінську структуру в'язничної адміністрації. Службі тюрем і пробації відтоді підпорядковуються 36 регіональних управлінь, у віданні яких безпосередньо знаходяться тюрми (1-2 у кожному регіоні), слідчі ізолятори та органи пробації [2, c. 112]. Загалом у Швеції 47 тюрем і 31 слідчий ізолятор [12, p. 75]. У середньому в'язниця розрахована на 45-80 осіб. У декількох великих тюрмах утримуються від 100 до 300 засуджених [1, с. 102].

За даними The World Prison Brief, станом на 2017 р. у місцях несвободи Швеції перебувало майже 6 тис. осіб (на 10 млн. населення країни - Авт.). 3 них 30\% - це особи, ув'язненні на етапі досудового слідства; 22\%. - іноземні громадяни; 6\% жінки [13]. За кількістю ув'язнених Швеція займає 112-е місце в світі.

В'язниці Швеції розподіляються за рівнем безпеки на 3 класи: 1, 2-го класу - закриті установи, 3-го в'язниці відкритого типу. У межах одного закладу можуть функціонува- ти сектори різного рівня безпеки. До якого закладу поміщати злочинця, вирішує суд при призначенні покарання, на основі оцінки ризиків. Установи 1-го класу призначені для засуджених, які мають високий рівень суспільної небезпеки та ймовірність втеч яких є досить високою. Установи 2-го класу можуть мати різний ступінь та форму моніторингу й контролю. У відкритих закладах утримуються особи, що вчинили ненасильницькі злочини, або ті, хто вже відбув частину строку покарання у в'язниці більш суворого режиму.

Незалежно від типу закладу, Служба тюрем і пробації Швеції особливу увагу звертає на умови утримання правопорушників. Вони не повинні відчувати, що їх життя менш значуще, ніж інших людей. Одяг засуджених, умови праці, проживання та відпочинку мають бути максимально наближені до тих, що $є$ в суспільстві. Таким чином досягається «нормалізація» як одна 3 цілей тюремного ув'язнення. Цьому повинні сприяти і дружні стосунки між персоналом і засудженими, що повсякчас заохочується. Кожного працівника закріплюють як куратора за 410 засудженими. Він надає їм консультації, допомогу при визначенні психологічних чи реабілітаційних програм тощо [12, р. 77-78].

На прикладі в'язниці Кумла (Anstalten Kumla) - однієї з найсуворіших у Швеції, розглянемо установи 1 класу безпеки. Kumla розташована в маленькому однойменному містечку. Загальна кількість персоналу в'язниці - 465 працівників, 3 яких жінок - 42 \%. Засуджених - близько 400. Плинність кадрів невелика - 8\%. Середній вік співробітників - 42 роки. Отримують вони приблизно 
300 тисяч шведських крон на рік [14].

У блоці «В» відбуває покарання 31 особа. Для зручності спостереження за ними блок розділений на два ідентичних крила. Усі камери в цій в'язниці одиночні. Замикаються вони лише на ніч. Щоранку двері камер відчиняють, і засуджені можуть залишати їх. Блок «В» вважається одним 3 найбільш благополучних у тому сенсі, що тут утримуються особи, не схильні до втеч. Але, незважаючи на це, скло на вікнах куленепробивне, а охорона веде загальне відеоспостереження цілодобово. $\mathrm{y}$ центрі блоку, між двома крилами, розташоване міні-КПП - скляна кімнатка, де постійно перебувють кілька співробітників, що стежать за порядком. У середині кімнати - монітори, спецзасоби та ін. [15].

Що стосується розпорядку дня у в'язницях Швеції, то порівняно 3 українськими установами виконання покарань, він достатньо м'який: підйом о 8.00 (тоді ж автоматично відмикаються двері камер), далі - сніданок, навчання, робота або участь у програмі реабілітації; об 11.00 - повернення в загальну зону для обіду; 11.45 - прогулянка на свіжому повітрі упродовж не менше години; 3 13.00 до 16.00 - навчання, робота або участь у програмі реабілітації; о 16.00 - вечеря, після якої до 20.00 вільний час; о 20.00 - відбій, двері камер автоматично замикаються на всю ніч.

Із засудженими постійно працюють соціальні працівники, вихователі та психологи, які багато розповідають про цінності сім'ї. На цьому засновані майже всі програми реабілітації. Шведські експерти вважають, що ймовірність учинення жорстоких злочинів людиною, яка виросла в благополучній сім'ї, набагато нижча. У цій в'язниці є кілька спортивних залів, волейбольні та баскетбольні майданчики, вуличний басейн та студія звукозапису [15].

У Швеції, як вже було зазначено, засуджені зобов'язані працювати. В середньому це - 6 годин на день упродовж 5 днів на тиждень [16]. У в'язниці Kumla вони шиють сумки, шапки, роблять на них аплікації. Робота не важка, але пропускати ії не можна без поважних причин. До останніх відносять, наприклад, участь у програмі щодо позбавлення наркотичної залежності або навчання.

Окремий блок, що схожий на бункер, призначений для злісних порушників режиму відбування покарання. Це спецвідділення з'явилося після цілої серії втеч зі шведських в'язниць. Лише 2004 р. їх було 33. Одна з найгучніших - втеча трьох ув'язнених, серед яких - лідер злочинного угруповання Даніел Майорану. Цей випадок набув значного розголосу, очільник Служби тюрем подав у відставку, а міністерство юстиції вирішило виділити 80 мільйонів євро на будівництво спецблоків у трьох існуючих в'язницях 1 класу. $\mathrm{y}$ в'язниці Kumla у такому спецблоці по периметру струм, система шлюзів та електронні замки миттєвого блокування. Все це максимально унеможливлює втечу засуджених, які тут утримуються. Їм не дозволено спілкуватися один 3 одним. Вони практично весь час проводять в своїх камерах на самоті. Навіть на прогулянки їх виводять поодинці. Співробітники в'язниці не вступають 3 ними в розмови. Відеоспостереження, 
на відміну від звичайного блоку, - 24 години на добу. Слід зазначити, що, якими би жорсткими не були ці заходи, вони виявилися досить дієвими - жодної втечі з Kumla більше не було [15].

Засади функціонування в'язниць 2-го класу розглянемо на прикладі установи Beateberg (Anstalten Beateberg). У ній утримується 40 засуджених. Така ж чисельність персоналу. В'язниця ділиться на секції. У кожній 5 одиночних камер, загальний душ, шафа для взуття, телефон (можна телефонувати куди завгодно, якщо на телефонній картці $\epsilon$ гроші). При цьому телефон автономний, слухавку можна просто забрати в камеру і там розмовляти 3 родичами. Двоповерхова будівля в'язниці більше схожа на офісне приміщення чи на лікарню. Засуджені проживають в одиночних камерах, що замикаються лише на ніч. Увесь інший час вони вільно переміщаються по корпусу і території, що обнесена сітчастим парканом 3 колючим дротом. Харчуються засуджені в їдальні. Їжу готують наймані працівники, але є можливість робити це самостійно.

У засуджених багато місць для відпочинку, де можна перебувати у вільний час. Людина повинна бути зайнята - це основа соціалізації пошведські. Графік робочого дня щільно розписаний. Відпочинок, в основному, активний: зал для ігор, зал для фітнесу. Існує кімната, де проводяться релігійні обряди. На базі установи функціонує велика бібліотека [17; 18].

Один із закладів 3-го класу відкрита вязниця Svartsjö, розташована у муніципалітеті Екеро. Anstalten Svartsjö оточений парканом
3 колючим дротом. У приміщеннях $\epsilon$ можливості для проведення дозвілля. $€$ тренажерний зал, солярій, сауна, столи для пінг-понгу, тенісний корт, міні-поле для гольфу. Діє бібліотека, оснащена комп'ютерами, але без доступу до мережі Internet. У ставку на території установи засуджені, у вільний від роботи час, можуть ловити рибу [19].

y Svartsjö засуджені працевлаштовані на фермі на території установи. Також вони працюють у столярних цехах, займаються інженерними роботами, обслуговують прилеглі паркові зони. Функціонує освітній центр, де засуджені мають змогу отримати професійно-технічне навчання. У вихідні та святкові дні передбачені візити родичів та близьких [20].

На сучасному етапі Швеція намагається розширити систему закладів останнього, 3 класу, що передбачають достатньо широкі можливості для засуджених, та застосовувати заходи покарання та впливу на правопорушників, що не пов'язані 3 позбавленням волі. Разом з тим, не відмовляючись остаточно від закладів з посиленими заходами безпеки i нагляду, з огляду на радикалізацію злочинних елементів, терористичну загрозу тощо.

Висновки. В'язнична система Швеції формувалася еволюційним шляхом починаючи від середини XIX ст., коли було організовано перші пенітенціарії, одиночні тюрми та центральні тюрми 3 примусовими роботами. Відмітною рисою пенітенціарної системи країни на цьому етапі було домінування суворого одиночного утримання за філадельфійською моделлю, що формально було скасовано лише 1945 р. Логічним

(C) Сокальська О. В., Ісевич О. І., 2018 
завершенням першого етапу тюремної реформи стало ухвалення 1864 р. Кримінального кодексу Швеції. На початку ХХ ст. впроваджено умовнодострокове звільнення та відстрочка тюремного ув'язнення з випробувальним строком.

Наступний етап реформ розпочався як наслідок зміни урядом соціал-демократів каральної політики держави. У 30-40 роках XX ст. фактично було закладено основи сучасної в'язничної системи Швеції як держави загального добробуту. Лейтмотивом змін стала теза про те, що засуджені повинні утримуватися в умовах, які б сприяли перетворенню їх у законослухняних громадян і пристосовували до життя в суспільстві. Особливе місце серед засобів виправлення відводилося праці засуджених. Сучасна система покарань та установ виконання покарань Швеції встановлена Кримінальним кодексом 1962 р. і модифікована впродовж 80-90 років XX ст. Виконання покарань у виді позбавлення волі регламентується Законом «Про позбавлення волі» 2010 р.

Орієнтуючись на досвід прогресивних західних країн у питаннях виконання покарань у виді позбавлення волі та побудови ефективної системи органів та установ виконання покарань, слід ураховувати й вивчати не лише їх сучасний стан, а й еволюційний шлях формування. Оскільки в'язничні моделі країн Західної Європи не виникли раптово, а $є$ результатом продуманої кримінально-виконавчої політики окремих країн, поступальних реформ, що тривали упродовж десятків або й сотні років. I досвід формування в'язничної системи Швеції та її сучасний стан чи не найкраще це підтверджує.

\section{Список використаних джерел}

1. Лисодєд О., Степанюк А. Покарання та громадські санкції у діяльності Служби тюрем і пробації Швеції. Вісник Академії правових наук України. 2003. № 4 (35). С. 99-109.

2. Лисодєд О., Степанюк А. Умови відбування покарання у тюрмах Швеції. Вісник прокуратури. 2003. № 6(24). С. 111-116.

3. Płatek M. Systemy penitencjarne państw skandynawskich : na tle polityki kryminalnej, karnej i penitencjarnej. Warszawa : Wydawnictwo Uniwersytetu Warszawskiego. 2007. 502 s.

4. Nilsson R. The Practise of Pastoral Power : The Swedish Prison Chaplains In The 19th century. Crime, Histoire et Sociétés. 2013. Vol. 17. №¹. URL: http:// https://journals.openedition.org/chs/1411 (дата звернення 09.09.2018).

5. Nilsson R. The Swedish Prison System in Historical Perspective: a Story of Successful Failure? Journal of Scandinavian Studies in Criminology and Crime Prevention. 2003. Volume 4. Issue 1. URL: https://doi.org/10.1080/14043850310010776 (дата звернення 10.10.2018).

6. Smith P. S., Ugelvik T. Scandinavian Penal History, Culture and Prison Practice : Embraced by the Welfare State. London, 2017. 456 p.

7. Shammas V. L. The Pains of Freedom: Prison Island and the Making of Scandinavian Penal Exceptionalism. Master's thesis, Sociology Department of Sociology and Human Geography. University Of Oslo. 2012. 100 p. URL : https://www.academia.edu/ 2570724/The_Pains_of_Freedom_Prison_Island_and_the_Making_of_Scandinavian_Penal_Exc eptionalism (дата звернення 11.10.2018). 
8. Монякова А. Тюремное дело в Швеции. Тюремный весник. 1906. № 1. С. 5770.

9. Sundell J.-O. Karl Schlyter - a Swedish Lawyer and Politician. P. 505-514. URL : http://www.scandinavianlaw.se/pdf/40-19.pdf (дата звернення 11.10.2018).

10. Уголовный кодекс Швеции URL : http://www.sweden4rus.nu/rus/info/ juridisk/ugolovnyj_kodeks_shvecii (дата звернення 10.10.2018).

11. Порівняльне кримінально-виконавче право : навч. посібник / за заг. ред. І. Г. Богатирьова. Київ : Інститут кримінально-виконавчої служби, 2013.140 с.

12. Hedstrom J. The American and Swedish Criminal Justice System: A Comparative Study (2018). Electronic Theses and Dissertations. Paper 3397. URL : https://dc.etsu.edu/etd/3397(дата звернення 11.10.2018).

13. The World Prison Brief.

URL: http://www.prisonstudies.org/country/sweden (дата звернення 11.10.2018).

14. Anstalten Kumla. URL : https:www.kriminalvarden.se/hitta-och-kontakta/ verksamhet/anstalt/kumla/ (дата звернення 10.10.2018).

15. Жизнь маньяков в шведской тюрьме. URL : https://www.google.com.ua/ amp/www.mk.ru/amp/social/2018/03/28/zhizn-manyakov-v-shvedskoy-tyurme-kruassanymuzykalnaya-studiya-basseyn.html (дата звернення 03.10.2018).

16. Lindström P., Leijonram E. The Swedish prison system. Ministry of Justice. 2007. P. 559-570.

17. Anstalten Beateber. URL: ghttps://www.kriminalvarden.se/hitta-ochkontakta/verksamhet/anstalt/beateberg/ (дата звернення 01.10.2018).

18. Исправительный центр (тюрьма) в Швеции. Часть первая. URL: https://seringvar.livejournal.com/1019770.html (дата звернення 07.10.2018).

19. Anstalten Svartsjö. URL: https://www.kriminalvarden.se/hitta-ochkontakta/verksamhet/anstalt/svartsjo/ (дата звернення 07.10.2018).

20. Anstalten Svartsjö.

URL: https://sv.wikipedia.org/wiki/Anstalten_Svartsj\%C3\%B6 (дата звернення 10.10.2018).

\section{O. Sokalska,}

PhD in Law, Associate Professor,

Senior Researcher of the Scientific-Research

Centre on Activities of the Bodies and

Establishments of the State Criminal-Executive

Service of Ukraine and Probation of Institute

of Criminal-Executive Service

o. Isevich,

Master Students of Institute of Criminal-

Executive Service

\section{PRISON SYSTEM OF THE KINGDOM OF SWEDEN: STAGES OF FORMATION AND MODERN STATE}

In Sweden the formation of the prison system began in the middle of the 19th century. As a result of the reform there were 3 penitentiary establishments for men and 1 for women; 46 solitary confinement prisons; 3 central prisons for the forced labour for men, 1 for women and 1 for young vagrants and juvenile offenders. The 
Philadelphia solitary confinement system was introduced in Sweden. It gave the possibility to achieve the high level discipline. It was formally canceled only in 1945.

In 1864 the Criminal Code of Sweden was adopted. It established the penal system and the relevant establishments for enforcement of sentences related to imprisonment.

The Social-Democratic Government began the next stage of the reforms. The Minister of Justice of Sweden Karl Schlyter advocated the restriction of using the imprisonment. He supported the differentiation of the penal establishments, in particular the creation of the special juvenile institutions for minors. The main task of the prison administration was to accustom the convicts to work and keep the order. The moral and educational influence should encourage the offenders to make the socially useful work, which gave them the possibility to return to the law-abiding life and secured their life after the release. The innovative views of the reformers were standardized in the Prison Regulations (1938) and The Protective Code (1945).

In 1962 the new Criminal Code of Sweden was adopted. It came into force in 1965 and laid the foundation for the modern penitentiary model. The special attention was paid to the «labour programme», which became the "calling card» of the Criminal-Executive System of Sweden at that time.

At present the enforcement of sentences, in particular the alternative measures, is entrusted to the Prison and Probation Service of the Ministry of Justice of Sweden. 36 regional departments are subordinated to it. Penal establishments, pre-trial institutions and probation bodies are under their jurisdiction.

Key words: Kingdom of Sweden, prison system, Karl Schlyter, penitentiary reform, Criminal Code of Sweden, labour of convicts, confinement conditions for the convicts.

Надійшла до редакції 12.10.2018 